The market pressures on British higher education are apparent everywhere. This year the government will introduce sizable tuition hikes, while shifting a sizeable fraction of student aid from grants to loans. A new report commissioned by the British Treasury urges closer industry ties and stronger alumni networks. "New Oxford," says historian Colin Lucas, Hood's predecessor, must promote technological innovation, cultural inclusiveness, and a greater international reputation-none of these familiar or easy undertakings.

The hard questions proliferate. Can Oxford extract the best lessons from the managerial and entrepreneurial mindset, without succumbing to that mindset's efficiency-driven excesses? Can it pay sought-after professors unequally, as it began doing only recently, while not undermining collegiality? Can it strengthen its graduate training while not slighting its commitment to undergraduate education? Will it move "from ivy-clad to Ivy League," the (London) Times Higher Education Supplement wondered-can it evolve into something other than a pallid version of a major American university? Since Oxford is Oxford, these questions matter.

"There is a will to move to the future-sort of," observes Anthony Hopwood, dean of the business school. The battles will doubtless be fierce, with the colleges, some of them richer than the university itself, jealously guarding their prerogatives. Since the faculty Congregation, the "parliament" of dons which would normally ratify the selection of the vice chancellor, never met before Hood's appointment, he lacks the academic equivalent of a mandate.

Still, the unconventional choice may prove inspired. John Hood-a thoroughly modern university manager, an outsider who's respectful of academic values and impatient with academic cant, passionate about excellence and equity - could be just the right man to wage the good fight against philistines and patricians alike.

Internet Resources

Visit our website for downloadable back issues of International Higher Education and other publications and resources at http://www.bc.edu/cihe/.

\section{Divided Government and Private Higher Education Growth in India}

\section{Asha Gupta}

Asha Gupta is currently engaged in postdoctoral research on vocationalization and privatization of higher education in India, with support from the University Grants Commission. She is a PROPHE-affiliated researcher. A former college principal, she is the author of Beyond Privatization (Macmillan, 2000). E-mail: ashagupta@vsnl.com.

IHE devotes a column in each issue to a contribution from PROPHE, the Program for Research on Private Higher Education, headquartered at the University at Albany. See http://www. albany.edu/ prophe.

\section{The Role of Federal and State Governments}

India has the second-largest higher education system in the world and the third-largest pool of skilled personpower. The system encompasses approximately 304 universities including 62 "deemed universities," 11 open universities, 14,600 colleges, 10 million students, and 0.5 million teachers. Besides these public and private institutions, the exact number of private colleges, international institutions, and enrollment involved in Indian higher education training and vocational skills is not yet known.

India's long tradition of private colleges and the current growth in private institutions have been facilitated by the lack of a restraining centralized national government. Prior to independence, many philanthropists and religiously oriented individuals and institutions established centers of higher learning to promote the values of spirituality, human dignity, and integrity. The usual orientation of private initiative and private funding was social transformation and leadership rather than monetary gains.

Even after independence, private initiative and households have played a substantial role in supporting higher education. Central government's share of total higher education income in 1950-1951 was just 49 percent. Although its funding rose to approximately 80 percent during the 1980s, since the 1990s government has resorted to cutbacks in higher education in the wake of structural adjustment, paving the way for the rapid expansion of self-financed private higher education. The pattern of government cutbacks and private expansion is familiar in much of Asia. Much less familiar is India's extended experience with college enrollments that were legally private but publicly financed.

Also unusual in India is the fact that central government provides only one-quarter of the funding for higher education, with much of the rest coming from 
the states. Both the federal and state governments can pass legislation pertaining to education. In case of any conflict between the two, federal law prevails. Though the federal government tried to regulate the private colleges in various states through the introduction of the Private Universities (Establishment and Regulation) Bill in 1995, this effort failed due to resistance from the private sector itself to the requirement of huge endowment funds, free tuition to approximately 30 percent of students, and regulation by the federal government. Instead of pursuing this bill further, the federal government adopted a policy of awarding the status of "deemed universities" to private institutions that met the national goals and criteria laid down by the University Grants Commission and other statutory bodies.

Under section 3 of the UGC Act (2000), deemed universities are required to possess viability and a management capable of contributing to university ideas and traditions. Under this scheme, the Manipal Academy, a pioneer in private higher education, has been granted the status of a deemed university. It is the only university that is totally self-financed, as most others have to rely on explicit or implicit public subsidies for their very survival.

Taking advantage of the provision for joint responsibility toward education, some states have passed their own legislation on private higher education recently. Chattisgarh was the first to pass a Private Universities Act, in October 2002. The newly emerged state of Uttaranchal succeeded in getting four private universities during 2002-2003. In fact, there has been a sudden proliferation of private medical and engineering colleges, especially in the southern and western states of India-namely, Andhra Pradesh, Tamil Nadu, Karnataka, Kerala, and Maharashtra.

For instance, in 2001, Andhra Pradesh had 95 private self-financing engineering colleges and 303 medical colleges in comparison to 11 public engineering colleges and 25 public medical colleges. In many states, private universities have started up in haste without adequate infrastructure and appropriate faculty. Those already functioning have raised fees sharply in conjunction with professional courses or foreign collaborations. Not surprisingly, these developments engendered public demonstrations and resentment, driving the judiciary to intervene.

\section{Recent Supreme Court Judgments}

The interventions by the Supreme Court from time to time and its contradictory judgments have only added to the prevailing confusion, however. India's Constitution guarantees various minorities, based upon religion or language, the right to establish and run institutions of higher learning. The idea was to allow these minorities to run educational institutions "for religious and charitable purposes." But shrewd politicians and businessmen took advantage of this provision, raising exorbitant amounts of money, legally or illegally, through capitation fees beyond the reach of many middle-class families.

In Unni Krishnan J. P vs. the State of Andhra Pradesh (1993), the Supreme Court banned the Capitation Fee Act, 1988. Instead, it allowed a number of "paid seats" to be established in consultation with concerned state governments. The idea was to make some families pay full costs toward the education not only of their own wards but also of some others, in the name of social justice. The state governments were also allowed to administer and regulate admissions into unaided and privately promoted institutions providing professional education.

In many states, private universities have started up in haste without adequate infrastructure and appropriate faculty.

However, in T. M. A. Pai vs. State of Karnataka (October 2002), the Supreme Court reversed its earlier Unni Krishnan stand and gave a green light to financially independent private and minority interests to establish higher education colleges of their choice. Although the court also warned against "commercialization" by private colleges, it was not clear what the practical impact of that warning might be.

In its most recent judgment (August 14, 2003), the Supreme Court has again taken a tough stand against capitation fees and profiteering by the private professional colleges. It has threatened to "de-recognize" private colleges found guilty of charging capitation fees in any form. Again, however, the impact remains unclear; there are reports, for example, of persistent underhanded dealings for obtaining seats in private professional colleges.

Notwithstanding the legal rulings, alliances among politicians, business, and academia sustain the commercialization of higher education for private gains. Thus, although democratic India stands out with the role taken by state governments and courts, it joins a powerful international trend of sharp growth in commercial private higher education, some tied to a new and dominant political economic marketplace and some to the lack of a firmer restraining political legal framework. 